\title{
PENGARUH STRATEGI PEMBELAJARAN DAN BAKAT MEKANIK TERHADAP HASIL BELAJAR PRAKTIK TEKNIK OTOMOTIF DI SMK
}

\author{
Suyanto, I Nyoman Sudana Degeng, Punaji Setyosari, Waras Kamdi \\ Teknologi Pembelajaran Pascasarjana Universitas Negeri Malang \\ Email: yantotgl@yahoo.com
}

\begin{abstract}
Abstrak: Tujuan penelitian ini adalah menguji signifikansi perbedaan hasil belajar pemahaman konsep dan keterampilan psikomotorik antara siswa dengan strategi pembelajaran kontekstual dan strategi pembelajaran langsung, perbedaan hasil belajar pemahaman konsep dan keterampilan psikomotorik antara siswa yang bakat mekanik tinggi dan bakat mekanik rendah, interaksi strategi pembelajaran dan bakat mekanik dalam perolehan hasil belajar pemahaman konsep dan keterampilan psikomotorik. Penelitian ini menggunakan rancangan Faktorial $2 \times 2$. Hasil penelitian ini menunjukkan bahwa strategi pembelajaran kontekstual lebih unggul dibanding strategi pembelajaran langsung, siswa berbakat mekanik tinggi lebih unggul dibanding siswa berbakat mekanik rendah, tidak ada interaksi yang signifikan antara strategi pembelajaran dan bakat mekanik pada hasil belajar pemahaman konsep dan keterampilan psikomotorik.
\end{abstract}

Kata kunci: pembelajaran kontekstual, pembelajaran langsung, bakat mekanik, hasil belajar.

\section{PENDAHULUAN}

Salah satu bentuk proses perbaikan pembelajaran adalah pengembangan strategi pembelajaran. Pengembangan strategi pembelajaran yang dibutuhkan adalah strategi pembelajaran yang kaya informasi dan bermakna serta mewujudkan kegiatan dinamis dan berpikir tingkat tinggi. Pengujian keefektifan strategi pembelajaran kontekstual dan strategi pembelajaran langsung dilakukan dengan pembuatan/penyusunan perangkat pembelajaran berfokus pada pengujian perbedaan hasil belajar praktik Pekerjaan Dasar Teknik Otomotif siswa kelas X Teknik Otomotif SMK dengan strategi pembelajaran kontekstual dan strategi pembelajaran langsung, serta melibatkan bakat mekanik sebagai variabel moderator. Tujuan penelitian ini adalah menguji signifikansi perbedaan hasil belajar pemahaman konsep dan keterampilan psikomotorik antara siswa dengan strategi pembelajaran kontekstual dan strategi pembelajaran langsung. Menguji signifikasi perbedaan hasil belajar pemahaman konsep dan keterampilan psikomotorik antara siswa yang bakat mekanik tinggi dan bakat mekanik rendah. Menguji signifikasi interaksi strategi pembelajaran dan bakat mekanik dalam perolehan hasil belajar pemahaman konsep dan keterampilan psikomotorik.

Teknik pembelajaran untuk SMK hendaknya dapat menciptakan sistem belajar yang komprehensif, perhatian, dan tanggung jawab. Cara menciptakannya adalah dengan mengembangkan studi dan investigasi dalam konteks yang kaya informasi dan bermakna serta mewujudkan kegiatan dinamis dan kemampuan berpikir tingkat tinggi. Stevenson (2003) menyatakan bahwa peranan utama guru bidang teknik adalah mengajar, melatih, dan mendidik untuk mengembangkan diri siswa secara mandiri dalam konteks yang berbeda. Untuk itu strategi pembelajaran di SMK dituntut menyesuaikan lingkungan kerja.

Permasalahan yang ada di sekolah hendaknya dipelajari, dirumuskan dan dicarikan pemecahan melalui kegiatan penelitian. Salah satu pemecahan yang dapat menjadi solusi dari permasalahan ini adalah strategi pembelajaran yang sesuai dengan kondisi siswa. Pembelajaran kontekstual adalah usaha mewujudkan stimulasi guru terhadap siswa sehingga siswa mendapat kesempatan yang cukup untuk dapat menyelidiki, memperdalam 
dan merekontruksi pengetahuan. Siswa tidak hanya menerima pengetahuan, namun juga mengonstruksi sendiri pengetahuannya melalui proses intraindividual (asimilasi dan akomodasi) dan inter-individual (interaksi sosial).

Strategi pembelajaran langsung dapat diterapkan pada mata pelajaran apapun, namun strategi ini lebih cocok untuk keterampilan psikomotor atau materi-materi yang membutuhkan penampilan unjuk kerja. Joyce and Weil (2004) mengemukakan lima fase penting dalam pembelajaran langsung, meliputi: (1) orientasi, (2) presentasi, (3) latihan terstruktur, (4) latihan terbimbing, dan (5) latihan mandiri. Sementara itu, menurut Kauchak and Eggan (1993) pembelajaran langsung terdiri dari empat fase, yaitu (1) perkenalan dan review, (2) presentasi, (3) latihan terbimbing, dan (4) latihan mandiri. Dalam pelaksanaannya siswa harus mengikuti petunjuk guru.

\begin{tabular}{lcr}
\multicolumn{1}{c}{ Beberapa } & hasil & penelitian \\
menyimpulkan & bahwa & strategi \\
pembelajaran & kontekstual & dapat \\
meningkatkan & perolehan hasil & belajar
\end{tabular}
aspek kognitif, afektif, maupun kinerja siswa. Corebima (2001) menyatakan bahwa strategi pembelajaran kontekstual telah teruji keunggulannya, baik terhadap hasil belajar maupun terhadap aspek kognitif lain dan perilaku siswa tetapi belum teruji pada aspek psikomotorik. Hasil penelitian Kevin dkk. (2012) menunjukkan bahwa pembelajaran kontekstual cocok digunakan untuk mengajarkan pengetahuan dan berpikir kritis dalam pembelajaran di SMK Pertanian. Sejalan dengan hal itu, Aer and Anikpa (2013) menjelaskan bahwa pembelajaran kontekstual dianggap sebagai strategi instruksi yang dapat membantu siswa memiliki kontak dengan ilmu pengetahuan dan teknologi bekerja. Selain mempunyai kelebihan, pembelajaran kontekstual mempunyai kekurangan diantaranya adalah memakan waktu untuk merencanakan strategi dan kurangnya ruang selama periode perencanaan serta siswa secara umum apatis (Smith, 2010). Oleh sebab itu, peneliti merasa tertarik untuk meneliti signifikansi pengaruh strategi pembelajaran kontekstual terhadap hasil belajar siswa pada mata pelajaran Pekerjaan Dasar Teknik Otomotif.

Selama ini pembelajaran praktik di SMK selalu dilaksanakan dengan strategi pembelajaran pola lama dimana guru yang berperan aktif atau strategi pembelajaran langsung. Maka dari itu, peneliti ingin membandingkan dengan pelaksanaan strategi pembelajaran dimana siswa yang berperan aktif yaitu strategi pembelajaran kontekstual. Untuk itu, peneliti meneliti pengaruh strategi pembelajaran kontekstual versus strategi pembelajaran langsung dengan memperhatikan bakat mekanik siswa sehingga bisa diperoleh hasil belajar pemahaman konsep maupun keterampilan psikomotor yang lebih baik.

\section{METODE}

Rancangan yang digunakan dalam penelitian ini adalah rancangan Faktorial 2 x 2 yaitu perlakuan/manipulasi dua variabel bebas atau lebih pada waktu bersamaan. Hal ini dilakukan untuk melihat efek masing-masing variabel bebas secara terpisah dan efek yang terjadi akibat adanya interaksi beberapa variabel. Pada penelitian ini dua kelompok subjek penelitian mendapatkan perlakuan sama, yaitu perlakuan strategi pembelajaran kontekstual dan perlakuan strategi pembelajaran langsung. Peneliti melakukan dua hal untuk mengontrol kesungguhan guru dalam mengajar. Pertama, sebelum guru mengajar dengan bereksperimen, peneliti memberikan latihan-latihan mengajar dengan bereksperimen (pilot studi) sesuai rencana penelitian. Kedua, ketika guru melaksanakan eksperimen, peneliti selalu memantau kegiatan tersebut.

Subjek penelitian ini adalah kelas X Teknik Otomotif (TO) SMKN 1 Trenggalek semester I tahun pelajaran 2014/2015 dengan jumlah siswa 130 (4 
kelas). Dua kelas TO dengan perlakuan strategi pembelajaran kontekstual dan dua kelas TO dengan perlakuan strategi pembelajaran langsung. Untuk menentukan kelompok penerima strategi PK atau PL, dilaksanakan pengundian.

Variabel yang digunakan dalam penelitian ini ada tiga, yaitu (1) variabel bebas (variable independent), (2) variabel moderator, dan (3) variabel terikat (variable devendent). Variabel Independen yang akan diteliti dalam penelitian ini adalah strategi pembelajaran kontekstual (PK) dan strategi pembelajaran langsung (PL). Variabel moderator yang diduga dapat memodifikasi pengaruh variabel bebas dalam penelitian adalah bakat mekanik. Variabel dependent yang akan diteliti sebagai pengaruh variabel bebas adalah hasil belajar pemahaman konsep merupakan variabel yang diukur berdasarkan hasil skor tes kemampuan siswa, menjawab soal dengan benar soalsoal kognitif dengan kualifikasi pengetahuan dan pemahaman.

Instrumen penelitian yang digunakan dalam penelitian ini dikelompokkan menjadi dua macam, yaitu (1) instrumen tes hasil belajar dan (2) instrumen tes bakat mekanik. Instrumen tes hasil belajar Teknik Otomotif di SMK disusun berdasarkan tujuan pembelajaran kelompok dasar kompetensi kejuruan (kelompok C2) di SMK, yaitu Pekerjaan Dasar Teknik Otomotif. Tes hasil kerja ini dikembangkan melalui analisis silabus Teknik Otomotif. Untuk mengukur hasil belajar yang berupa pengetahuan (pemahaman konsep) digunakan instrumen tes objektif yang berupa soal pilihan ganda dengan lima opsi jawaban. Untuk mengukur hasil belajar yang berupa keterampilan psikomotorik, digunakan instrumen tes unjuk kerja yang berupa soal unjuk kerja. Instrumen tes bakat mekanik dimaksudkan sebagai alat ukur kemampuan dasar pembelajar dalam memahami prinsip-prinsip prosedur dan hukum-hukum yang mendasari cara kerja peralatan mesin, listrik dan peristiwa alamiah yang ada dalam kehidupan seharihari (Mukhadis, 1993). Instrumen ini berupa tes untuk menentukan bakat mekanik tinggi dan bakat mekanik rendah, bentuk tes pilhan ganda (obyektif) dengan empat pilihan (option) jumlah enam puluh (60) butir soal. Untuk instrumen soal tes bakat mekanik ini dimiliki oleh lembaga psikolog, dan selalu dijaga kerahasiaannya.

Data dianalisis dengan teknik Manova 2 x 2 dengan taraf signifikan 0,05. Manova 2 × 2 memiliki dua keunggulan. Pertama, dapat mengontrol tingkat kesalahan eksperimen ketika terjadi beberapa derajat inter-korelasi di antara variabel dependen. Kedua, memiliki kemampuan menganalisis variabel yang lebih banyak daripada Manova biasa.

\section{HASIL}

Hasil penelitian ini menunjukkan: 1) strategi pembelajaran kontekstual lebih unggul dibanding strategi pembelajaran langsung pada hasil belajar pemahaman konsep; 2) siswa berbakat mekanik tinggi lebih unggul dibanding siswa berbakat mekanik rendah pada hasil belajar pemahaman konsep; 3) tidak ada interaksi yang signifikan antara strategi pembelajaran dan bakat mekanik pada hasil belajar pemahaman konsep siswa; 4) strategi pembelajaran kontekstual lebih unggul dibanding srategi pembelajaran langsung pada hasil belajar keterampilan psikomotorik; 5) siswa bakat mekanik tinggi lebih unggul dibanding siswa bakat mekanik rendah pada hasil belajar keterampilan psikomotorik; dan 6) tidak ada interaksi yang signifikan antara strategi pembelajaran dan bakat mekanik pada hasil belajar keterampilan psikomotorik siswa.

Hasil penelitian merupakan pemaparan tabulasi data yang diperoleh pada tahapan pengumpulan data dan uji statistik terhadap data-data tersebut. Sebelum dilaksanakan analisis data, dilakukan penskoran hasil pengukuran variabel prates, hasil postes pemahaman 
konsep, dan hasil uji keterampilan psikomotorik. Penelitian dilaksanakan di SMKN 1 Trenggalek pada siswa kompetensi keahlian Teknik Otomotif (TO) kelas X, yaitu kelas X TO1, X TO2, $\mathrm{X}$ TO3, dan $\mathrm{X}$ TO4 dengan jumlah 130 anak.

\begin{tabular}{|c|c|c|}
\hline \multicolumn{3}{|c|}{$\begin{array}{l}\text { Tabel 1. Sebaran Penelitian } \\
\text { Berdasarkan Strategi } \\
\text { Pembelajaran } \\
\end{array}$} \\
\hline Strategi Pembelajaran & $\begin{array}{c}\begin{array}{c}\text { Frekw } \\
\text { ensi }\end{array}\end{array}$ & $\begin{array}{c}\text { Persent } \\
\text { ase } \\
(\%)\end{array}$ \\
\hline $\begin{array}{l}\text { Pembelajaran Kontekstual } \\
\text { (PK) X TO1 dan X TO3 } \\
\text { Pembelajaran Langsung (PL) } \\
\text { X TO2 dan X TO4 }\end{array}$ & $\begin{array}{l}65 \\
65\end{array}$ & $\begin{array}{l}50 \% \\
50 \%\end{array}$ \\
\hline Jumlah & 130 & $100 \%$ \\
\hline
\end{tabular}

$\begin{array}{ccr}\text { Tes bakat mekanik } & \text { diberikan } \\ \text { kepada kedua } & \text { kelompok } & \text { strategi }\end{array}$ pembelajaran, yaitu kelompok siswa dengan perlakuan strategi pembelajaran konstektual dan kelompok siswa dengan perlakuan strategi pembelajaran langsung. Kelompok siswa dengan perlakuan strategi pembelajaran konstektual (PK) memperoleh skor maksimum 97, skor minimum 10, dan rentang $($ range $)=97-$ $10=87$. Kelompok siswa dengan perlakuan strategi pembelajaran langsung (PL) memperoleh skor maksimum 97, skor minimum 10, dan rentang $($ range $)=97$ $10=87$. Skor maksimum dan minimum dari kedua strategi pembelajaran itu sama.

Data hasil prates kelompok siswa dengan perlakuan strategi pembelajaran kontekstual (PK) dan data hasil prates kelompok siswa dengan perlakuan strategi pembelajaran langsung (PL) dianalisis dengan teknik statistik uji t. Analisis statistik ini untuk mengetahui tingkat kesetaraan kedua kelompok siswa yang diteliti. Hasil analisis statistik uji t tersebut tampak pada Tabel 2. berikut.

\section{Tabel 2.Hasil Analisis Uji t Terhadap Prates Kelompok PK dan Kelompok PL}

\begin{tabular}{|c|c|c|c|c|c|}
\hline $\begin{array}{l}\text { e } \\
\text { lajaran }\end{array}$ & $\begin{array}{l}\text { Metod } \\
\text { Pembe }\end{array}$ & $\mathrm{N}$ & Mean & \begin{tabular}{|c} 
Standa \\
r \\
Devias \\
i (SD)
\end{tabular} & $\begin{array}{l}\text { Std. } \\
\text { Error } \\
\text { Mean }\end{array}$ \\
\hline Nilai Prates Siswa & Langs & 65 & $\begin{array}{c}12.784 \\
6\end{array}$ & $\begin{array}{c}2.4905 \\
6\end{array}$ & $\begin{array}{c}.3089 \\
2\end{array}$ \\
\hline $\begin{array}{l}\text { ung } \\
\text { kstual }\end{array}$ & Konte & 65 & $\begin{array}{c}12.000 \\
0\end{array}$ & $\begin{array}{c}2.2220 \\
5\end{array}$ & $\begin{array}{c}.2756 \\
1\end{array}$ \\
\hline
\end{tabular}

Pada Tabel 2, terlihat bahwa rerata skor prates kelompok siswa dengan perlakuan strategi pembelajaran kontekstual (PK) memiliki mean 12,0000 dan SD 2,22205. Sementara itu, rerata skor prates kelompok siswa dengan perlakuan strategi pembelajaran langsung (PL) memiliki mean 12,7846 dan SD 2,49056. Hal itu berarti nilai hasil prates siswa PL lebih tinggi daripada hasil prates siswa PK.

Tabel 3. Hasil Analisis Uji t Dua Sampel Independen

\begin{tabular}{|c|c|c|c|c|c|c|c|c|c|c|}
\hline & \multirow{2}{*}{\multicolumn{2}{|c|}{$\begin{array}{c}\text { Levene's } \\
\text { Test for } \\
\text { Equality } \\
\text { of } \\
\text { Variances }\end{array}$}} & \multicolumn{7}{|c|}{$\mathrm{t}$-Test for Equality of Means } \\
\hline & & & & \multirow[b]{2}{*}{$\mathrm{T}$} & \multirow[b]{2}{*}{ Df } & \multirow{2}{*}{$\begin{array}{c}\text { Sig. } \\
(2- \\
\text { tailed } \\
)\end{array}$} & \multirow{2}{*}{$\begin{array}{c}\text { Mean } \\
\text { Differenc } \\
\text { e }\end{array}$} & \multirow{2}{*}{$\begin{array}{c}\text { Std. } \\
\text { Error } \\
\text { Differenc } \\
\mathrm{e}\end{array}$} & \multicolumn{2}{|c|}{$\begin{array}{c}95 \% \\
\text { Confidence } \\
\text { Interval of the } \\
\text { Difference }\end{array}$} \\
\hline & & $\mathrm{F}$ & Sig. & & & & & & \begin{tabular}{|c} 
Lowe \\
$\mathrm{r}$
\end{tabular} & Upper \\
\hline \multirow{2}{*}{$\begin{array}{l}\text { Nilai } \\
\text { prate } \\
\text { s } \\
\text { sisw } \\
\text { a }\end{array}$} & \begin{tabular}{|l|} 
Equal \\
variance \\
$\mathrm{s}$ \\
assumed
\end{tabular} & $\begin{array}{c}3.77 \\
0\end{array}$ & $\begin{array}{c}.05 \\
4\end{array}$ & $\begin{array}{c}1.89 \\
5\end{array}$ & 128 & .060 & .78462 & .41399 & $\begin{array}{c}.0345 \\
4\end{array}$ & $\begin{array}{c}1.6037 \\
7\end{array}$ \\
\hline & \begin{tabular}{|l|} 
Equal \\
variance \\
s not \\
assumed \\
\end{tabular} & & & $\begin{array}{c}1.89 \\
5\end{array}$ & $\begin{array}{c}126.37 \\
0\end{array}$ & .060 & .78462 & .41399 & $\begin{array}{c}.0346 \\
4\end{array}$ & $\begin{array}{c}1.6038 \\
7\end{array}$ \\
\hline
\end{tabular}

Pada Tabel 3, tampak bahwa nilai uji Lavene sebesar 3,770 dengan nilai signifikansi (p) sebesar 0,054 dan test equality $\mathrm{p}>0,05$. Dapat disimpulkan bahwa ragam data dari hasil prates pemahaman konsep praktik Pekerjaan Dasar Teknik Otomotif di SMKN 1 Trenggalek adalah homogen sehingga dapat dilakukan pengujian dengan uji $t$ independen dengan asumsi ragam data yang homogen (equal variance assummed).

Hasil uji $t$ independen menunjukkan nilai signifikansi prates pemahaman konsep praktik Pekerjaan Dasar Teknik Otomotif di SMKN 1 Trenggalek sebesar $0,060(p>0,05)$ antara siswa dengan perlakuan strategi pembelajaran kontekstual (PK) dan siswa dengan perlakuan strategi pembelajaran 
langsung (PL). Artinya, hasil prates pemahaman konsep praktik Pekerjaan Dasar Teknik Otomotif di SMKN 1 Trenggalek menunjukkan bahwa antara kelompok siswa dengan strategi PK dan kelompok siswa dengan strategi PL tidak ada perbedaan yang bermakna $(p>0,05)$ sehingga dapat dinyatakan sebagai $\mathrm{H} 0$ (hipotesis nol). H0 adalah tidak ada perbedaan nilai rata-rata di antara dua kelompok karena kedua kelompok tersebut memiliki kemampuan yang setara.

Berdasarkan hasil analisis postes hasil belajar, dapat disimpulkan beberapa hal. Pertama, hasil belajar pemahaman konsep dan keterampilan psikomotorik secara bersama-sama berbeda pada kelompok siswa dengan perlakuan strategi pembelajaran kontekstual dan siswa dengan perlakuan strategi pembelajaran langsung. Kedua, hasil belajar pemahaman konsep dan hasil belajar keterampilan psikomotorik secara bersama-sama berbeda pada kelompok siswa yang mempunyai bakat mekanik tinggi dan bakat mekanik rendah. Ketiga, tidak ada interaksi yang signifikan antara strategi pembelajaran (baik kontekstual maupun langsung), dan bakat mekanik terhadap hasil belajar siswa (baik pada pemahaman konsep maupun pada keterampilan psikomotorik).

Berdasarkan hasil analisis dan uji hipotesis menggunakan Manova 2 x 2, dapat disimpulkan beberapa hal, sebagai berikut. (1) Terdapat perbedaan hasil belajar pemahaman konsep yang signifikan antara siswa yang diajar dengan strategi pembelajaran kontekstual dan srategi pembelajaran langsung. (2) Terdapat perbedaan hasil belajar pemahaman konsep yang signifikan antara siswa bakat mekanik tinggi dan bakat mekanik rendah.

\section{PEMBAHASAN}

Pembahasan ini berfokus pada pengaruh utama dan pengaruh interaksi antarvariabel penelitian, yaitu strategi pembelajaran, bakat mekanik, dan hasil belajar praktik teknik otomotif.

\section{Pengaruh Strategi Pembelajaran terhadap Hasil Belajar Pemahaman Konsep dan Keterampilan Psikomotorik}

Hipotesis pertama menyatakan bahwa ada perbedaan yang signifikan antara kelompok siswa yang diajar menggunakan strategi pembelajaran kontekstual dengan kelompok siswa yang diajar menggunakan strategi pembelajaran langsung terhadap hasil belajar pemahaman konsep. Ternyata, hasil analisis statistik deskripsi memang menunjukkan bahwa pembelajaran kontekstual bisa memberikan nilai hasil belajar yang lebih tinggi daripada pembelajaran langsung. Terdapat perbedaan hasil belajar antara kelompok siswa yang diberi perlakuan strategi pembelajaran kontekstual (PK) dan kelompok siswa yang diberi perlakuan strategi pembelajaran langsung (PL).

Penerapan strategi pembelajaran kontekstual secara signifikan memberi pengaruh yang lebih baik daripada strategi pembelajaran langsung terhadap perolehan hasil belajar pemahaman konsep. Strategi pembelajaran kontekstual dapat memudahkan siswa karena strategi pembelajaran ini membantu guru mengaitkan antara materi yang diajarkan dengan situasi dunia nyata siswa, serta mendorong siswa membuat hubungan antara pengetahuan yang dimilikinya dengan penerapannya dalam kehidupan mereka sebagai anggota keluarga, warga negara, dan pekerja (Johnson, 2002). Dengan demikian, secara empirik terbukti bahwa penerapan strategi pembelajaran kontekstual lebih berpengaruh daripada penerapan strategi pembelajaran langsung dalam menentukan hasil belajar pemahaman konsep.

Menurut Johnson (2007), pembelajaran kontekstual adalah sebuah sistem yang merangsang otak untuk menyusun pola-pola yang mewujudkan 
makna. Kontekstual merupakan suatu sistem pengajaran yang cocok untuk otak yang menghasilkan makna dengan menghubungkan muatan akademis dan konteks dari kehidupan sehari-hari siswa. Penerapan pembelajaran kontekstual pada kerja bangku siswa SMK Teknik Otomotif (konteks) memberi kesempatan kepada siswa berlatih/praktik secara langsung dalam membuat benda kerja. Pembelajaran kontekstual adalah sesuatu pembelajaran yang kompleks dan multidimensional yang jauh melampaui berbagai metodologi serta hanya berorientasi pada latihan dan rangsangan. Penerapan strategi pembelajaran kontekstual pada suatu pembelajaran memiliki pengaruh yang positif terhadap hasil belajar siswa. Hasil penelitian Danielson, Bander, Milss, Vwermeer and Lockee (2003) menyatakan bahwa dengan pembelajaran kontekstual maka kemampuan pemecahan masalah siswa dapat meningkat, karena siswa terbiasa dihadapkan dengan masalahmasalah pembelajaran dan solusinya.

$$
\text { Selanjutnya, Raharso }
$$

menunjukkan bahwa proses dengan menggunakan model pembelajaran kontekstual memberikan hasil yang lebih optimal daripada model pembelajaran konvensional. Hal ini diperkuat hasil penelitian-penelitian yang lain. Amir (2007) yang menyimpulkan bahwa pendekatan pembelajaran kontekstual secara signifikan memberi pengaruh yang lebih baik terhadap hasil belajar siswa daripada pendekatan pembelajaran konvensional. Senada dengan itu, hasil penelitian Warpala (2006) menyimpulkan bahwa pendekatan kontekstual lebih unggul dan lebih efektif dari pendekatan konvensional dalam pencapaian hasil belajar siswa pada mata pelajaran IPA. Temuan penelitian Khalid and Azeem (2012), terbukti bahwa metode pengajaran konstruktivis dalam pengajaran keterampilan komunikasi bahasa Inggris jauh lebih baik dibandingkan untuk metode tradisional. Dengan demikian pembelajaran kontekstual mempunyai hasil yang lebih dibanding dengan pembelajaran langsung.

Strategi pembelajaran kontekstual lebih unggul daripada strategi pembelajaran langsung. Dalam pembelajaran kontekstual siswa didorong untuk terlibat aktif dalam belajar, baik individu maupun kelompok, mencari pemecahan masalah-masalah yang diangkat sebagai topik pembelajaran. Hal itu dalam mengondisikan siswa untuk mengembangkan potensi berpikir dan mencari solusi pemecahan masalah. Dengan demikian, siswa tidak hanya dituntut menghafal, tetapi juga belajar secara aplikatif. Kondisi ini akan membiasakan siswa untuk belajar seumur hidup (long life learning) sehingga pada masa depan siswa akan menjadi manusia yang mampu hidup mandiri dan memecahkan masalahnya sendiri dalam kehidupan nyata.

\section{Pengaruh Bakat Mekanik terhadap Hasil Belajar Pemahaman Konsep dan Keterampilan Psikomotorik}

Hasil penelitian ini menunjukkan bahwa ada perbedaan yang signifikan antara siswa yang berbakat mekanik tinggi dan siswa yang berbakat mekanik rendah terhadap hasil belajar pemahaman konsep. Hal ini menunjukkan bahwa bakat mekanik, baik tinggi maupun rendah, memiliki pengaruh terhadap hasil belajar pemahaman konsep pada mata pelajaran Pekerjaan Dasar Teknik Otomotif di SMK. Hal serupa juga tampak pada hasil belajar keterampilan psikomotorik. Ternyata hasil penelitian ini juga menunjukkan bahwa ada perbedaan yang signifikan antara siswa yang berbakat mekanik tinggi dengan siswa yang berbakat mekanik rendah terhadap hasil belajar keterampilan psikomotorik pada mata pelajaran Pekerjaan Dasar Teknik Otomotif di SMK.

Bakat mekanik mempunyai peran penting pada diri pembelajar dalam proses pembelajaran, yaitu memberikan dampak terhadap hasil belajar sebagai hasil akhir dari proses pembelajaran. Siswa yang tidak memiliki bakat mekanik bila bekerja 
pada bidang mekanik hasil kerjanya tidak akan optimal. Seorang siswa yang mempunyai bakat mekanik tinggi lebih mudah menerima pelajaran yang diberikan oleh guru, dan terampil dalam melaksanakan kegiatan praktik pembuatan benda kerja dibanding siswa yang mempunyai bakat mekanik rendah. Dengan ini, diperoleh hasil akhir pembelajaran yang berbeda, di mana perolehan hasil belajar pembelajar dengan bakat mekanik tinggi lebih unggul dibanding dengan bakat mekanik rendah, baik secara individu maupun kelompok.

$$
\text { Runco dan Albert (1987) }
$$

menemukan perbedaan yang signifikan antara lisan dan skor figural siswa berbakat dan tidak berbakat, yakni siswa yang mempunyai bakat lebih tinggi hasil belajarnya memahami konsep dalam suatu teks. Hal ini diperkuat dengan penjelasan Munandar (1982) bahwa ada hubungan positif antara aktualisasi kemampuan potensial (bakat) yang dimiliki anak SD dengan tingkat ketekunan, keuletan, ketelitian, dan kemandirian.

\section{Interaksi antara Strategi Pembelajaran dan Bakat Mekanik}

Hasil temuan penelitian ini menunjukkan bahwa tidak ada interaksi yang signifikan antara strategi pembelajaran dan bakat mekanik terhadap hasil belajar siswa. Menurut Kerlinger and Lee (2000) kerja sama antardua variabel bebas atau lebih dapat berpengaruh terhadap suatu variabel terikat. Hal ini sejalan dengan pendapat Ghozali (2008) yang mengemukakan bahwa pengaruh interaksi adalah pengaruh bersama atau joint effect antardua atau lebih variabel independen terhadap variabel dependen. Interaksi terjadi manakala suatu variabel bebas tidak membawa akibat secara terpisah. Sebaliknya, interaksi tidak terjadi apabila suatu variabel bebas membawa akibat secara terpisah. (1) Hasil pengujian hipotesis tidak ada interaksi antara strategi pembelajaran dan bakat mekanik terhadap hasil belajar pemahaman konsep, berdasarkan hasil analisis tes multivariat yang ditunjukkan pada tabel 4.9 memperlihatkan hasil uji didapatkan nilai F sebesar 0,119 dan nilai signifikansi probability 0,731 . Nilai probability tersebut jauh lebih tinggi dari taraf signifikansi 0,05. Dengan demikian, H0 diterima sehingga tidak ada interaksi antara strategi pembelajaran kontekstual dan bakat mekanik terhadap hasil belajar pemahaman konsep. (2) Hasil pengujian hipotesis tidak ada interaksi antara strategi pembelajaran dan bakat mekanik terhadap hasil belajar keterampilan psikomotorik, berdasarkan hasil analisis tes multivarian yang ditunjukkan pada tabel 4.9 memperlihatkan hasil uji didapatkan nilai F sebesar 1,855 dan nilai signifikansi probability 0,176 . Nilai probability tersebut jauh di atas taraf signifikansi 0,05. Dengan demikian, H0 diterima sehingga tidak ada interaksi antara strategi pembelajaran kontekstual dan bakat mekanik terhadap hasil belajar keterampilan psikomotorik.

\section{Implikasi Hasil Penelitian terhadap Pembelajaran}

Hasil penelitian ini diharapkan memiliki implikasi yang bermanfaat pada beberapa pembelajaran. Pertama, penerapan strategi pembelajaran kontekstual lebih unggul bila dibandingkan dengan strategi pembelajaran langsung dalam meningkatkan hasil belajar siswa. Untuk itu, strategi pembelajaran kontekstual dapat dijadikan sebagai salah satu alternatif strategi yang dapat digunakan untuk pembelajaran praktik Pekerjaan Dasar Teknik Otomotif dengan kompetensi dasar menggunakan dan merawat macam-macam hand tools sesuai SOP dengan penilaian tugas membentuk benda dengan gergaji, kikir dan peralatan lain di SMK. Pembelajaran kontekstual memberikan peluang lebih besar pada siswa untuk mengembangkan kreativitas dalam membangun pemahaman konsep dan keterampilan psikomotorik. 
Pembelajaran kontekstual juga bisa mendorong siswa untuk belajar mandiri dalam merencanakan dan menentukan strategi memecahkan masalah belajar.

Pada proses pembelajaran kompetensi dasar menggunakan dan merawat macam-macam hand tools sesuai SOP dengan penilaian tugas membentuk benda dengan gergaji, kikir, dan peralatan lain mata pelajaran praktik Pekerjaan Dasar Teknik Otomotif pada kompetensi keahlian Teknik Otomotif di SMK, diperlukan sebuah strategi pembelajaran yang cocok dan efektif untuk memberikan hasil belajar pemahaman konsep dan keterampilan psikomotorik. Untuk itu, guru berperan sebagai pembimbing siswa dalam membentuk pengetahuan baru, membuat makna, konsep kerja sama, konsep aplikasi hal-hal yang telah dipelajari melalui suatu proyek, sehingga hasil pembelajaran diharapkan semakin meningkat.

Kedua, bakat mekanik memiliki peran yang penting dalam pembelajaran. Bakat mekanik dalam diri siswa akan memengaruhi pembentukan pengetahuan dan keterampilan siswa sehingga memberikan pengaruh pada peningkatan hasil belajar siswa yang diharapkan. Siswa yang memiliki bakat mekanik tinggi hasil belajarnya lebih baik dari pada siswa yang memiliki bakat mekanik rendah, baik pada kelas eksperimen maupun kontrol. Perbedaan yang dipengaruhi oleh bakat mekanik yang dimiliki siswa dalam belajar, siswa dengan bakat mekanik tinggi mempunyai daya tangkap cepat bisa dalam mengikuti pembelajaran baik pemahaman konsep maupun keterampilan psikomotorik. Siswa yang mempunyai bakat mekanik rendah cenderung terkesan kurang cepat dalam menerima pembelajaran baik pemahaman konsep maupun keterampilan psikomotorik.

Bakat merupakan aspek penting yang berkaitan dengan performance akademik siswa. Oleh karena itu, variabel yang dipertimbangkan sebagai salah satu faktor penting yang memengaruhi hasil dan proses pembelajaran. Untuk itu guru hendaknya terus membina dan memotivasi terhadap siswa yang memiliki bakat mekanik tinggi dan bagi yang mempunyai bakat mekanik rendah terus diberikan latihan-latihan untuk meningkatkan hasil belajar.

Ketiga, interaksi antara strategi pembelajaran dan bakat mekanik tidak berpengaruh terhadap hasil belajar baik pemahaman konsep maupun keterampilan psikomotorik pada mata pelajaran Pekerjaan Dasar Teknik Otomotif. Hal ini menunjukkan bahwa strategi pembelajaran tidak bergantung pada bakat mekanik siswa dalam meningkatkan hasil belajar. Dengan kata lain, bakat mekanik siswa tidak memengaruhi efektivitas strategi pembelajaran dalam meningkatkan hasil belajar siswa. Bagaimanapun kondisi bakat yang dimiliki siswa, terbukti bahwa strategi pembelajaran kontekstual dapat meningkatkan hasil belajar siswa secara signifikan. Hasil analisis menunjukkan bahwa strategi pembelajaran kontekstual lebih efektif daripada strategi pembelajaran langsung dalam meningkatkan hasil belajar siswa, baik pada aspek pemahaman konsep maupun aspek psikomotor.

\section{PENUTUP}

Simpulan

Berdasarkan pembahasan hasil penelitian Pengaruh Strategi Pembelajaran dan Bakat Mekanik terhadap Hasil Belajar Praktik Teknik Otomotif di SMK, dapat dibuat enam simpulan. (1) Ada perbedaan hasil belajar pemahaman konsep siswa dengan perlakuan strategi pembelajaran konstekstual dan dengan perlakuan strategi pembelajaran langsung. Kelompok siswa dengan perlakuan strategi pembelajaran kontekstual lebih baik hasil belajarnya dibandingkan kelompok siswa dengan perlakuan strategi pembelajaran langsung. Hal ini menunjukkan bahwa ada peningkatan hasil pemahaman konsep setelah diberikan perlakuan, yaitu strategi 
pembelajaran kontekstual pada kelas eksperimen dibandingkan kelas kontrol yang menggunakan perlakuan strategi pembelajaran langsung. (2) Ada perbedaan hasil belajar pemahaman konsep siswa yang memiliki bakat mekanik tinggi dan yang mempunyai bakat mekanik rendah. Kelompok siswa yang mempunyai bakat mekanik tinggi hasilnya lebih baik dibandingkan siswa yang mempunyai bakat mekanik rendah. Hal ini menunjukkan bahwa ada peningkatan hasil pemahaman konsep setelah melihat siswa yang mempunyai bakat mekanik tinggi dibandingkan siswa yang mempunyai bakat mekanik rendah. Dengan demikian, siswa yang mempunyai bakat mekanik tinggi dapat mencapai hasil belajar pemahaman konsep lebih baik dibandingkan dengan siswa yang mempunyai bakat mekanik rendah. (3) Tidak ada interaksi antara strategi pembelajaran dan bakat mekanik terhadap perolehan hasil belajar pemahaman konsep. Artinya, strategi pembelajaran dan bakat mekanik tidak memberikan pengaruh terhadap perolehan hasil belajar pemahaman konsep. (4) Ada perbedaan hasil belajar keterampilan psikomotorik siswa yang dengan perlakuan strategi pembelajaran konstekstual dan siswa dengan perlakuan strategi pembelajaran langsung. Kelompok siswa dengan perlakuan strategi pembelajaran kontekstual hasil belajarnya lebih baik dibandingkan kelompok siswa dengan perlakuan strategi pembelajaran langsung. Hal ini menunjukkan bahwa ada peningkatan hasil keterampilan psikomotorik setelah diberikan perlakuan strategi pembelajaran kontekstual pada kelas eksperimen dibandingkan kelas kontrol yang menggunakan strategi pembelajaran langsung. (5) Ada perbedaan hasil belajar keterampilan psikomotorik siswa yang mempunyai bakat mekanik tinggi dan siswa yang mempunyai bakat mekanik rendah. Kelompok siswa yang mempunyai bakat mekanik tinggi hasilnya lebih baik dibandingkan siswa yang mempunyai bakat mekanik rendah. Hal ini menunjukkan bahwa ada peningkatan hasil belajar keterampilan psikomotorik setelah melihat siswa yang mempunyai bakat mekanik tinggi dibandingkan siswa yang mempunyai bakat mekanik rendah. Dengan demikian siswa yang mempunyai bakat mekanik tinggi dapat mencapai hasil belajar keterampilan psikomotorik yang lebih baik dibandingkan dengan siswa yang mempunyai bakat mekanik rendah. (6) Tidak ada interaksi antara strategi pembelajaran dan bakat mekanik terhadap perolehan hasil belajar keterampilan psikomotorik. Artinya, strategi pembelajaran dan bakat mekanik tidak memberikan pengaruh terhadap perolehan hasil belajar keterampilan psikomotorik.

\section{Saran}

Saran-saran yang disampaikan dalam penelitian ini antara lain: (1) Guru Teknik Otomotif diharapkan menggunakan strategi pembelajaran kontekstual untuk meningkatkan kualitas pembelajaran praktik. Dengan menggunakan strategi pembelajaran kontekstual, siswa akan mendapatkan kesempatan untuk mengumpulkan fakta, mengonstruksi, memahami, memberikan makna, dan bekerja-sama dalam kegiatan pembelajaran. (2) Penerapan strategi pembelajaran kontekstual untuk praktik Teknik Otomotif membutuhkan daya kreasi dan inovasi guru. Hal ini disebabkan pembelajaran kontekstual adalah pembelajaran yang mengaitkan antara materi dengan konteks kehidupan nyata, sedangkan materi praktik Teknik Otomotif selalu berkaitan dengan peristiwa di lingkungan sekitar kita. Oleh sebab itu, guru Kompetensi Dasar Teknik Otomotif mampu merancang pembelajaran dengan menyediakan berbagai sumber belajar atau memberikan petunjuk kepada siswa untuk mengakses berbagai sumber belajar yang dapat digunakan untuk mengonstruksi pengetahuan dan materi pelajaran. (3) Bakat mekanik siswa memiliki pengaruh yang kuat terhadap hasil belajar teknik 
otomotif di SMK, khususnya untuk kelompok siswa yang dengan perlakuan strategi pembelajaran kontekstual. Oleh sebab itu, guru diharapkan memahami bakat mekanik peserta didik. Dengan memahami bakat mekanik siswa maka guru akan mendapatkan bahan masukan di dalam merancang pembelajaran yang akan dilakukan. Jika ini dilakukan maka guru dapat memberdayakan potensi yang dimiliki oleh siswa secara maksimal.

Kepada para pembuat kebijakan pendidikan di Indonesia, yaitu guru, Kepala Sekolah, Pengawas Sekolah, Kepala Dinas Pendidikan dan praktisi yang lain, misalnya peneliti yang ingin mengembangkan desain pembelajaran kontekstual sehingga dapat melaksanakan penelitian lebih lanjut yang berkaitan dengan hasil-hasil penelitian ini. Pada penelitian ini mengkaji Pengaruh Strategi Pembelajaran Kontekstual vs Strategi Pembelajaran Langsung, dan Bakat Mekanik terhadap Hasil Belajar Praktik Pekerjaan Dasar Teknik Otomotif di SMK, dengan kompetensi dasar menggunakan dan merawat macam-macam hand tools sesuai dengan SOP. Untuk itu disarankan kepada praktisi pendidikan, guru, dan peneliti untuk mengkaji strategi pembelajaran dan bakat mekanik terhadap perolehan hasil belajar jenis mata pelajaran praktik di SMK, misalnya Teknik Kendaraan Ringan, Teknik Sepeda Motor, dan mata pelajaran pada paket keahlian yang lain di lingkup kompetensi keahlian Teknik Otomotif di SMK. Adapun harapan kelanjutan penelitian ini untuk meningkatkan mutu pendidikan di daerah, sekolah khususnya, dan umumnya Negara Tercinta Republik Indonesia.

\section{DAFTAR RUJUKAN}

Aer, I. \& Anikpa, P.O. 2013. Contextual Teaching and Learning: A Strategy for Developing Grain Full Skills Through Science and Technology Education. Department of Integrated Science and Department of Physics, Federal Collegeof
Education. Obudu, Cross River State. (Online). (www.global academicgroup.com/journals.

Diakses, 20 Maret 2015).

Amir, 2007. Pengaruh Penerapan Pembelajaran Kontektual dan Kecakapan Motorik terhadap Perolehan Hasil Belajar Kerajinan Tangan dan Kesenian Siswa Kelas $V$ Sekolah Dasar. Disertasi tidak diterbitkan. Malang: PPS Universitas Negeri Malang.

Corebima, D.T. 2001. Pembelajaran Kontekstual. Jakarta: Direktorat Sekolah Lanjutan Pertama. Dikdasmen Depdiknas.

Danielson, J.A., Bander, H.S., Milss, E.M., Vwermeer, P.J \& Lockee, B.B. 2003. A Tool for Helping Veterinary Lear Diagnostic Problem Solving. Education Technology Research and Development, 51(3): 63-81.

Ghozali, I. 2008. Design Eksperimental, Teori, Konsep dan Analisis Data dengan SPSS. Semarang: Badan Penerbitan Universitas Diponegoro.

Johnson, E.B. 2002. Contextual Teaching and Learning. California: Cowin Press Inc.

Joyce, B. \& Weil, M. 2004. Models of Teaching. 7th ed. Boston: Allyn and Bacon.

Kauchak, D.P. \& Eggan, P.D. 1993. Learning and Teaching: Research Based Methods. Boston: Allyn \& Bacon.

Kerlinger, F.N. \& Lee, H.B. 2000. Foundations of Behavioral Research. (4 ${ }^{\text {th }}$ Edition). Orlando: Hacourt College Publisher.

Kevin, W., Wilson, E., Farin, C.E. \& Bunga, J.L. 2012. Scientific Basis vs. Contextualized Teaching and Learning: The Effect on the Achievement of Postsecondary Students. Journal of Agricultural Education, 53(1): 57-66 DOI: 
10.5032/jae.2012.01057. Diakses:

19 Maret 2015.

Khalid K. \& Azeem M. 2012. Constructivist Vs Traditional: Effective Instructional Approach in Teacher Education. International Journal of Humanities and Social Science.

http://www.ijhssnet.com/journals/

Vol_2_No_5_March_2012/21.pdf.

Diakses 1 September 2015.

Mukhadis

A. 1993. Pengaruh

Pengorganisasian Isi Prosedural,

Locus of Control dan Bakat

Berfikir Mekanik terhadap Hasil

dan Transper Belajar di Sekolah

Teknologi Menengah Kodya

Malang. Desertasi tidak

diterbitkan. Malang: PPS IKIP

Malang.

Munandar, U. 1995. Kreativitas dan Keberbakatan: Strategi Mewujudkan Potensi Kreatif dan Bakat. Jakarta: Gramedia Pustaka.

Raharso, S. 2007. Implementasi Problem Based Learning di Perguruan Tinggi. Jurnal Ilmu Pendidikan. 34(1): 55-61.

Runco, M.A. \& Albert, R.S. 1987. The Threshold Hypothesis Regarding Creativity and Intelegence: And Empirical Test With Gifted and Nongifted Children. Creat. Child Adult Q Journals, 11 (3): 212-218.

Smith, P. 2010. Implementing the Contextual Teaching and Learning Pedagogical Model. Journal of Family \& Consumer Sciences Education, http://www.natefacs.org/Pages/v28 no1/v28no1Smith.pdf. 28 (1): 23-36, diakses 4 Pebruari 2015.

Stevenson. J. 2003. Developing Vocational Expertise. Sydney: Allen \& Unwin.

Warpala, W.S. 2006. Pengaruh Pendekatan Pembelajaran dan Strategi Belajar Kooperatif terhadap Pemahaman dan Keterampilan Berfikir Kritis Siswa Kelas $V$ SD di Kecamatan
Kubutambahan. Disertasi tidak diterbitkan Malang: PPS Universitas Negeri Malang. 